\title{
Short and Improved Synthesis of Cytotoxic Homodimers with an Isoquinoline Structure
}

\author{
PAULINA MEZA, SILVANA VACCARO, JUDITH FAUNDES, RODRIGO SEGURA, \\ JUANA ANDREA IBACACHE* \\ Facultad de Química y Biología, Universidad de Santiago de Chile, Alameda 3363, Casilla 40, Santiago 9170022, Chile.
}

\begin{abstract}
The syntheses of cytotoxic homodimers 5, 7-10 are described. Compounds 5, 7-10 were cleanly and efficiently obtained by microwave activation. A thorough study concerning oxidative reaction of diamines and isoquinolinequinones, under ultrasound (US) and microwave (MW) irradiation is presented. Under MW irradiation the yields are higher, the amount of precursor quinone used decreases substantially, the reaction time decreases considerably (from hours to minutes) in respect to previously reported methodology.
\end{abstract}

Keywords: Homodimers, Isoquinolınequinones, Microwave, Ultrasound

\section{Introduction}

The synthesis of functionalized quinones has been an important focus due to their several biological activities [1-3], where the aminoquinonline-and aminoisoquinoline-5,8-quinone scaffold appears in different cytotoxic natural compounds [4,5], such as, cribrostratin 3[6], caulibugulones AF[7] and streptonigrin [8]. Aminoquinoline- and aminoisoquinoline-5,8-quinone scaffolds appear as the key structural components of a variety of naturally occurring antibiotics such as streptonigrin [6,7], lavendamycin [8,9], cribrostratin 3 [10], caulibugulones A-C [11], and mansouramycins A-C [12].

The biological processes involved with the antitumor activity of quinones are DNA intercalation, alkylating and/or redox-cycling mechanism $[9,14]$ making them promising polymodal drugs. Due to the fact that quinones are electroactive, they can be easily reduced by one or two electrons to form the semiquinone radical anion $\left(\mathrm{Q}^{*}\right)$ or hydroquinone dianion $\left(\mathrm{Q}^{2-}\right)$, generating Reactive Oxygen Species (ROS) such as hydrogen peroxide, superoxide and hydroxyl radical, which oxidize lipids, proteins and DNA [11,15-17]; thus it is redox-cycling the most associated quinone mechanism [18,19].

Regarding the redox properties of quinones, their reduction potential can be moderate [20] by the insertion of electron-donor or electron-withdrawing groups, displacing their two redox processes a more negative or positive values, respectively [21-24].

Therefore, the optimization of synthetic routes to obtain new derivatives is an important aspect to have in consideration. In that framework, ultrasound and microwave-assisted techniques have become an important methods to improve organic synthesis [25-32]. Concerning ultrasound-assisted technique, it has been demonstrated that it can accelerate the reaction rates at room temperature [29,31,33], and it has been used in different types of reactions, such as coupling reactions, Reformatsky reaction, Michael addition reaction, Diels-Alder reaction, Mannich-type reaction, among others [29,33-35]. On the other hand, the Microwave-assisted technique, has been a breakthrough in organic synthesis, since has exhibit several improvements, such as uniform heating, higher reaction rate, reproducibility, reduction in unwanted side reactions, eco-friendly, among others [36-38].

Considering the advantages of these techniques for Michael additions [33-35,39,40], in this work is presented the optimized synthesis of cytotoxic and selective mono- and dimers based on aminoisoquinolinequinones previously reported [41], and their electrochemical characterization. In summary, the syntheses of cytotoxic homodimers have been accomplished by employing the MW

\footnotetext{
*email: juana.ibacache.r@usach.
} 
irradiation. This new approach were cleanly and efficiently which confirms great utility of microwave stimulation in oxidative coupling reactions for preparing dimeric structures based on isoquinolinequinones.

\section{Materials and methods}

\subsection{Chemistry}

All solvents and reagents were purchased from different companies such as Aldrich (St. Louis, MO, USA) and Merck (Darmstadt, Germany) and were used as supplied. Melting points were determined on a Stuart Scientific SMP3 (Bibby Sterilin Ltd., Staffordshire, UK) apparatus and are uncorrected. The IR spectra were recorded on an FT-IR Bruker spectrophotometer; (model Vector 22 Bruker, Rheinstetten, Germany), using $\mathrm{KBr}$ disks, and the wave numbers are given in $\mathrm{cm}^{-1} .{ }^{1} \mathrm{H}-$ and ${ }^{13} \mathrm{C}$-NMR spectra were recorded on a Bruker Avance-400 instrument (Bruker, Ettlingen, Germany) in $\mathrm{CDCl}_{3}$ at 400 and $100 \mathrm{MHz}$, respectively. Silica gel Merck 60 (70-230 mesh, from Merck, Darmstadt, Germany) was used for preparative column chromatography, and TLC aluminum foil 60F254 for analytical thin layer chromatography (TLC). Isoquinolinequinones 1-4 were prepared by previously reported procedures $[42,43]$.

The ultrasound-promoted reactions were carried out in standard oven-dried glassware in a Branson sonicator cup horn working at $19.7-20.0 \mathrm{kHz}(75 \mathrm{~W})$. The microwave-assisted procedures were carried out in Anton Paar Microwave 300 synthesis reactor. A microwave oven operating at 30-50W.

\section{Synthesis of Homo- and Heterodimers 5, 7-10. General procedure}

A $10-\mathrm{mL}$ microwave vial was charged with quinone 1-4 (1 mmol), the 4,4'-diaminodiphenymethane $(2 \mathrm{mmol}), \mathrm{CeCl}_{3} \times 7 \mathrm{H}_{2} \mathrm{O}(5 \mathrm{mmol} \%)$ and ethanol $(5 \mathrm{~mL})$. The resulting reaction mixture was irradiated for $45 \mathrm{~min}$ at $70^{\circ} \mathrm{C}$ inside the microwave oven at 30-50 W until the completion reaction (TLC). The solvent was removed on a rotary evaporator and the crude product was purified by column chromatography over silica gel $\left(95: 5 \mathrm{CH}_{2} \mathrm{Cl}_{2} / \mathrm{EtOAc}\right)$ to yield the corresponding pure dimer compound 5, 7-10.

\section{Electrochemical measurement}

The electrochemical measurements were performed at room temperature, using a platinum electrode and DMF/tetrabutylammonium perchlorate. Before the measurements, the solution was deoxygenated using $\mathrm{N}_{2}$ as purging gas for $15 \mathrm{~min}$. The half-wave potential $\left(\mathrm{E}_{1 / 2}\right)$ of the quinone compounds were characterized by cyclic voltammetry in a potential range from 0.0-2.0 V, at a sweep rate of $50 \mathrm{mVs}^{-1}$.

\section{Results and discussions}

To study the reaction, the effects of the solvents and reagent activation techniques were considered, whether reflux (conventional thermal stirring) studies, presence or absence of $\mathrm{CeCl}_{3} \times 7 \mathrm{H}_{2} \mathrm{O}$ catalyst, tests under cavitation (unconventional), reaction $\mathrm{MW}$-assisted and quinone:diamine molar ratio. The results are shown in Table 1.

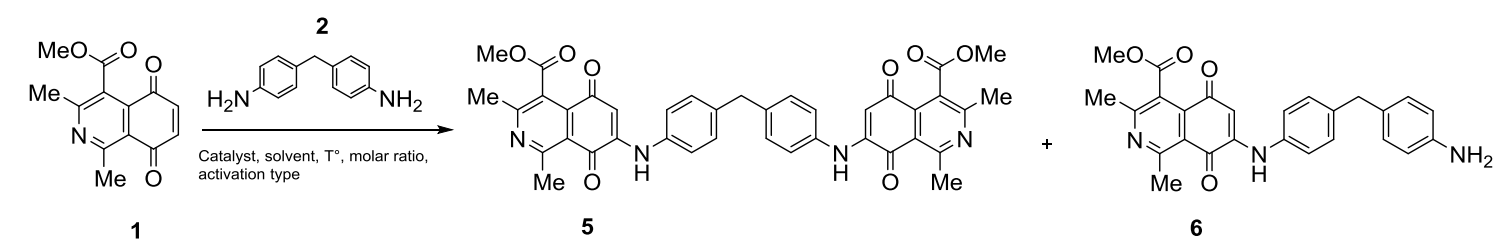

Scheme 1. Products from the reaction of quinone 1 with diamine 2 
Table 1. Study of reaction conditions for synthesis homodimer 5

\begin{tabular}{|c|c|c|c|c|c|c|c|}
\hline Entry & Solvent & $\begin{array}{c}\text { Ratio } \\
\text { quinone: } \\
\text { diamine } \\
(\mathrm{mmol})\end{array}$ & $\begin{array}{l}\text { Catalyst } \\
(\mathrm{mmol})^{\mathrm{a}}\end{array}$ & Reaction activation & $\begin{array}{c}\text { Time } \\
\text { (minutes) }\end{array}$ & 5, Yield $\%^{\mathrm{f}}$ & $\begin{array}{c}\text { 6, Yield } \\
\%^{\mathrm{f}}\end{array}$ \\
\hline 1 & ethanol & $4: 1$ & 0.05 & Without sonication $^{\mathrm{b}}$ & 900 & 70 & 20 \\
\hline 2 & water & $4: 1$ & 0.05 & Without sonication ${ }^{\mathrm{b}}$ & 1440 & 41 & 58 \\
\hline 3 & ethanol & $4: 1$ & 0.05 & Without sonication ${ }^{\mathrm{c}}$ & 420 & 35 & 65 \\
\hline 4 & ethanol & $4: 1$ & 0.05 & With sonication $^{\mathrm{d}}$ & 240 & 98 & ND \\
\hline 5 & ethanol & $4: 1$ & 0.05 & With sonication $^{\mathrm{d}}$ & 120 & 45 & 51 \\
\hline 6 & water & $4: 1$ & 0.05 & With sonication ${ }^{\mathrm{d}}$ & 240 & 86 & 6 \\
\hline 7 & water & $4: 1$ & 0.05 & With sonication ${ }^{\mathrm{d}}$ & 120 & 39 & 59 \\
\hline 8 & water & $4: 1$ & - & With sonication $^{\mathrm{d}}$ & 240 & 50 & 45 \\
\hline 9 & water & $2: 1$ & 0.05 & With sonication & 240 & 55 & 25 \\
\hline 10 & water & $4: 1$ & 0.05 & $\mathrm{MW}^{\mathrm{e}}$ & 45 & 61 & ND \\
\hline 11 & ethanol & $4: 1$ & 0.05 & $\mathrm{MW}^{\mathrm{e}}$ & 45 & 89 & 9 \\
\hline 12 & ethanol & $4: 1$ & 0.05 & $\mathrm{MW}^{\mathrm{e}}$ & 90 & 27 & 55 \\
\hline 13 & ethanol & $4: 1$ & - & $\mathrm{MW}^{\mathrm{e}}$ & 45 & 74 & 12 \\
\hline 14 & ethanol & $2: 1$ & 0.05 & $\mathrm{MW}^{\mathrm{f}}$ & 45 & 94 & ND \\
\hline
\end{tabular}

First, a mixture of quinone 1 and diamine 4,4'-diaminodiphenylmethane react in a 4:1 (mmol) ratio at room temperature in the presence of catalysts, using ethanol or water as solvent (Table 1, entries 1, 2 and 3). The progress of the reaction monitored by TLC revealed that the amination reaction progressed slowly and without consuming completely the reaction's limiting diamine, so the reaction was stopped after 900 min (entry 1). The homodimer 5 was obtained in $70 \%$ yield together with the corresponding monomer 6 in $20 \%$ yields (entry 1 ). When the solvent was water (entry 2) the reaction time increased considerably, and the main product was monomer $\mathbf{6}$, with $60 \%$ of the pure product. Entries 1-3 indicate that the use of ethanol favors the formation of dimer $\mathbf{5}$, which is related to the solubility (monomer $\mathbf{6}$, and dimer 5, are quite insoluble solids in water precipitating in the reaction medium). Entries 1-3 also indicate that longer reaction times will favor monomer $\mathbf{6}$, formation. Then the activation source of the reaction was changed, heating under reflux, in which case it was seen that although the reaction time decreased to $420 \mathrm{~min}$, the proportion of monomer 6 was $65 \%$, greater than that of the homodimer of interest 5. Considering that the best results were those of trial 1 , it was decided to study the effect of ultrasound irradiation on the reaction, in which the reaction conditions of trial 1 were maintained, applying ultrasound energy in cellular disruptor cup, it should be noted during the ultrasound irradiation, the temperature of the mixture was controlled with ice bath where the temperature was maintained in room temperature (entries 4 and 5). In trial 4 it is seen that carrying out the reaction for 240 min 98\% homodimer and not determined yield of monomer was obtained. Decreasing the time to 120 min (entry 5) a higher percentage of monomer (58\%) was obtained compared to the homodimer of interest (45\%). The experimental results showed that the ultrasound energy quickly activates the reaction and favors the formation of the dimer 5, improves the yield of the desired product (homodimer 5, 98\%, entry 2) and decreases the reaction times compared to the reaction performed without sonicate (homodimer $\mathbf{5}, 70 \%$, entry 1). This indicates that, apparently, the dimer $\mathbf{5}$ is formed rapidly with respect to the monomer $\mathbf{6}$, at low temperatures. Then, to assess the scope of a more sustainable method, water was used as the solvent, maintaining the reaction's activation with ultrasound (entries 6 and 7). It is seen that carrying out the reaction for $240 \mathrm{~min}$ the corresponding homodimer 5 is obtained as the main product, with $86 \%$ yield. To confirm the need for a catalyst, trial 8 was performed in the absence of the catalyst. From the table, it can be concluded that although the synthesis can occur without catalyst (entries 8 and 13), $\mathrm{CeCl}_{3} \times 7 \mathrm{H}_{2} \mathrm{O}$ clearly plays a role in the selectivity of the process, improving the yields in the dimer 5. Could be ascribed by coordination of 
the catalyst with the nitrogen atom and/or the carbonyl oxygen at the 5-position of the isoquinoline system $^{42}$, which makes the quinonic system more electrophylical and reactive, not only in the first addition (monomer formation) but also in the second addition (dimer formation). To improve the atomic economy, trial 9, in which the proportion of quinone was decreased, was carried out.

Then it was decided to study the effect of applying microwave energy at $70^{\circ} \mathrm{C}$ (entries $10-14$ ). Note that entry 14, allowed obtaining homodimer 5 with a yield of $94 \%$, in a time of 45 min and with a quinone molar ratio: diamine 2:1. According to these results, we have obtained an improved method compared to that already reported for the synthesis of homodimers ${ }^{41}$, since we have reduced the reaction time from $240 \mathrm{~min}$ to $45 \mathrm{~min}$, we have reduced the relation molar quinone:diamine from 4:1 to $2: 1$, using ethanol as the solvent for the reaction.

The result suggests that thermodynamic and kinetic rather aspects should play an important role in the selectivity control of dimer, 5/monomer 6 .

It is observed that at lower reaction times the formation of dimer $\mathbf{5}$ is favored, with respect to monomer 6. Additionally it is observed that increasing the temperature for long periods of time decreases the formation of dimer $\mathbf{5}$, and increases that of monomer $\mathbf{6}$. This apparently indicates that monomer $\mathbf{6}$ is formed more slowly than dimmer $\mathbf{5}$, but has greater stability at higher temperatures. Therefore there is a dimer / monomer balance; wherein dimer 5, corresponding to the kinetically favored product and monomer $\mathbf{6}$, will be the thermodynamically favored product. It should be noted that additional studies are necessary to confirm the experimental results obtained.

The homodimer 5 was isolated as a red solid, m.p.199-201 ${ }^{\circ} \mathrm{C}$. The IR spectrum reveals the presence of $\mathrm{N}-\mathrm{H}, \mathrm{C}=\mathrm{O}$ and aromatic nuclea bands at $\mathrm{v} / \mathrm{cm}^{-1}: 3446(\mathrm{NH}), 1736$ (ester $\left.\mathrm{C}=\mathrm{O}\right), 1677$ (quinone $\mathrm{C}=\mathrm{O}$ ) and 1618 (aromatic nuclea), respectively.

Having optimized the reaction conditions (entry 14 - Table 1), the syntheses of various cytotoxic homodimers were carried out, starting from isoquinolinequinones 1-4. We obtained compounds 5, 7-9 (Scheme 2). When using as starting material isoquinolinequinone $\mathbf{3}$, the reaction product was a mixture of symmetric homodimer $\mathbf{8}$ and asymmetric homodimer 10, that was separated by preparative chromatography (TLC aluminum foil $60 \mathrm{~F} 254$ for analytical thin-layer chromatography TLC, 95:5 $\left.\mathrm{CH}_{2} \mathrm{Cl}_{2} / \mathrm{EtOAc}\right)$

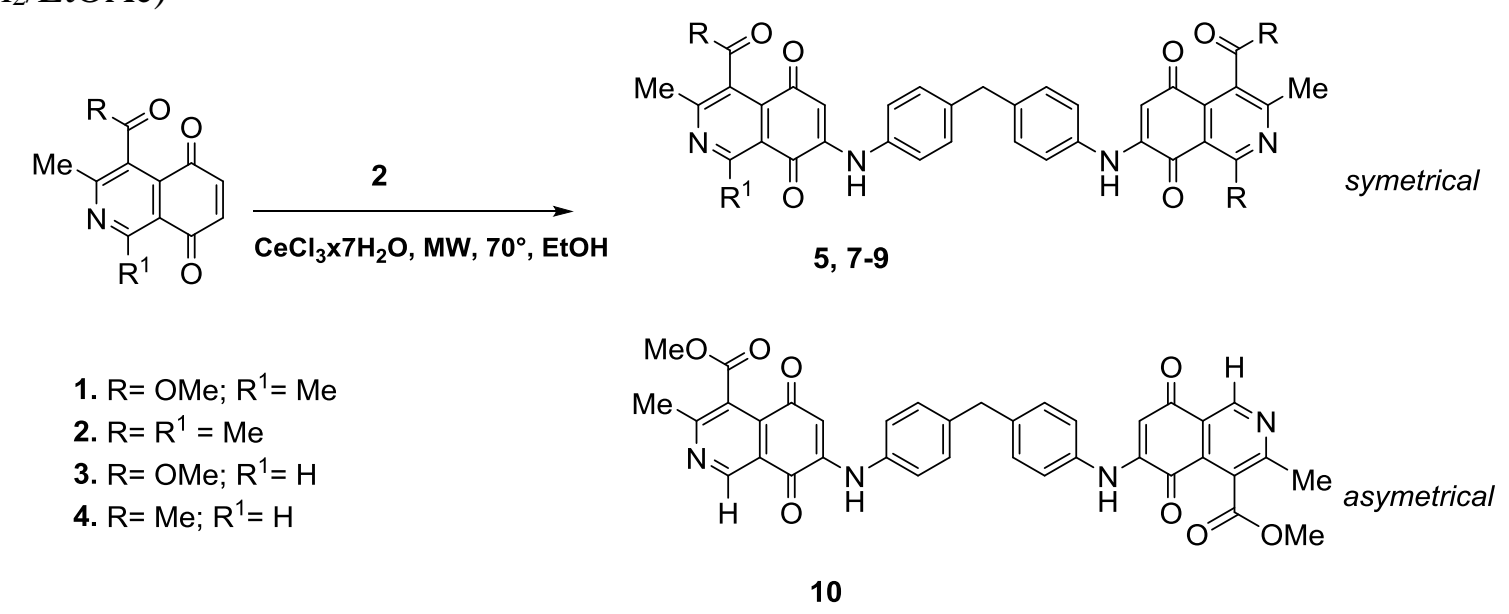

Scheme 2. Synthesis of symmetrical homodimers 5, 7-9 and asymmetrical homodimer .

The compounds 5, 7-9 was prepared in 55-94\% from the respective isoquinolinequinones $\mathbf{1 - 4}$ and diamine 4, 4'-diaminodiphenylmethane $\mathbf{2}$, according to the new methodology presented in this work. All yields were significantly increased compared to the previously reported methodology and it should be noted that asymmetrical homodimer 10, which shows the most cytotoxic potencies and high selectivity index (mean $\mathrm{IC}_{50}=0.37 \mu \mathrm{M}$; $\mathrm{SI}=6.97$ ) in the series, was synthesized in $45 \%$ nearly to $50 \%$ yield previously reported by our research group [41] (Table 2). 
The structures of compounds were fully characterized by infrared spectroscopy (IR), ${ }^{1} \mathrm{H}-$ and ${ }^{13} \mathrm{C}$ nuclear magnetic resonance (NMR), bidimensional nuclear magnetic resonance (2D-NMR), and high resolution mass spectroscopy (HRMS).

The cytotoxic activity of the quinoid compounds is related to the redox properties of the electroactive quinone moiety, the redox potential of these compounds could provide important clues on their biological activity; consequently, their study is relevant.

The redox potentials of the homodimers 5, 7-10 and monoamination compounds $\mathbf{6 , 1 1 - 1 4}$, were measured by cyclic voltammetry at room temperature, using a platinum electrode and DMF/ tetrabutylammonium perchlorate. The voltammograms were run in the potentials range 0.0-2.0 V, at a sweep rate of $50 \mathrm{mVs}-1$, as $\mathrm{E}_{1 / 2}=\left(\mathrm{E}_{\mathrm{pa}}+\mathrm{E}_{\mathrm{pb}}\right) / 2$, where $\mathrm{E}_{\mathrm{pa}}$ correspond to anodic and cathodic peak potentials, respectively. Two quasi-reversible waves were observed for compounds 5-7-10-14, in the negative region of the cyclic voltammograms.

Table 2. Yields and redox potentials of univalent- and divalent phenylaminoisoquinolinequinone derivatives

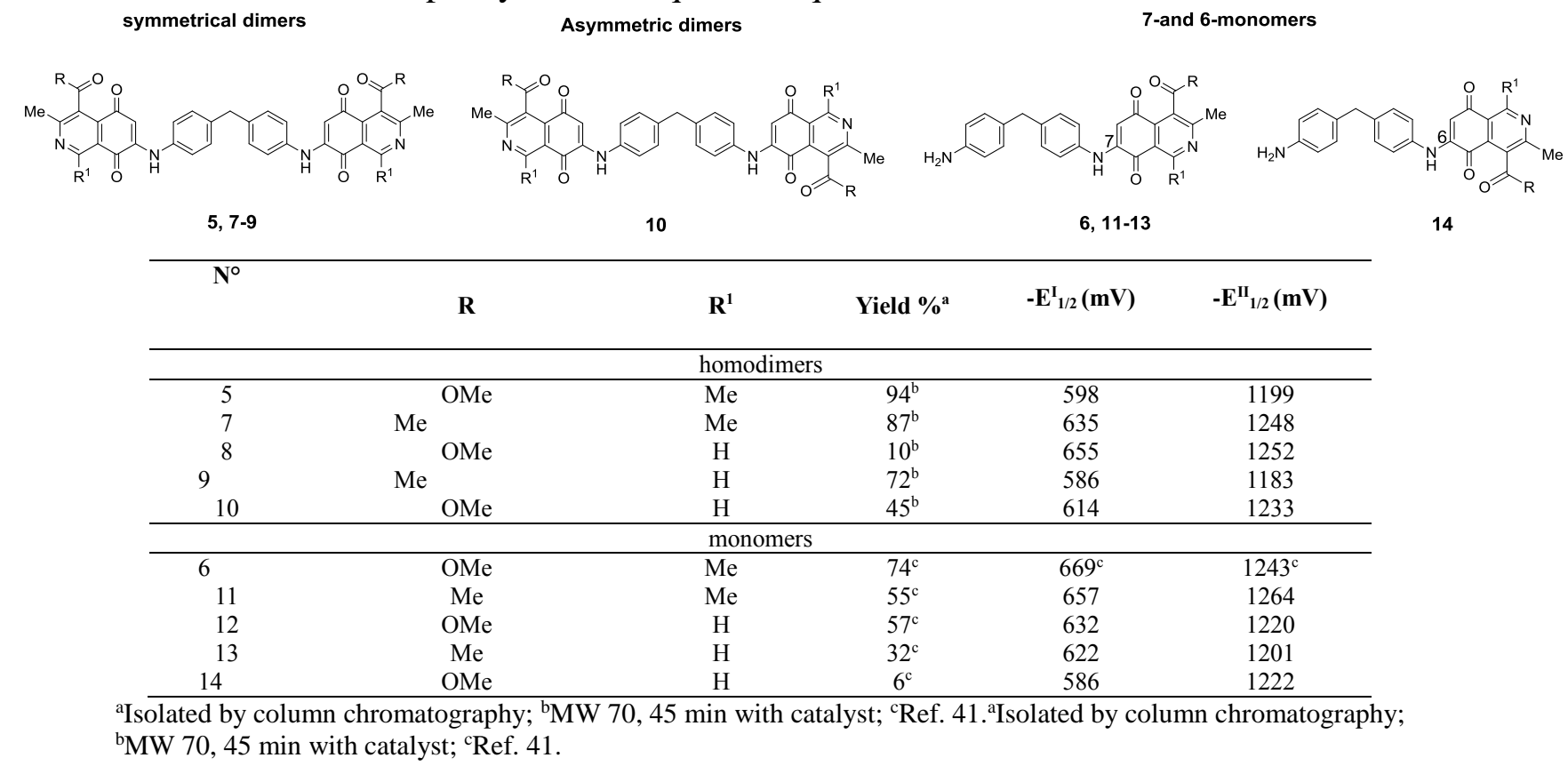

The Figure 1 shows the redox behavior of the mono- and disubstituted diaminodiphenylmethane with isoquinolinequinone moieties $\mathbf{6}$ and $\mathbf{5}$ respectively, which occurs in two-quasi-reversible waves in the negative region of the cyclic voltammograms. Despite the homodimer $\mathbf{5}$ having two quinone moieties, it presents, similarly to the monomer derivative, two redox processes. This is due to the symmetry of the molecule and it has been shown in a precedent work that the bivalent compounds presents a two-electron-transfer in each process [44]. 


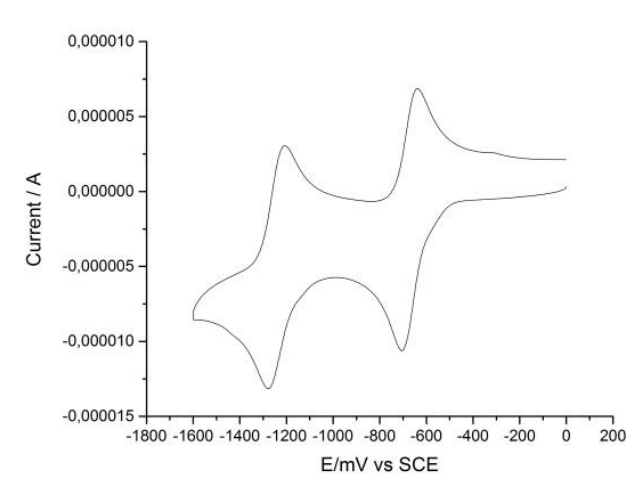

(a)

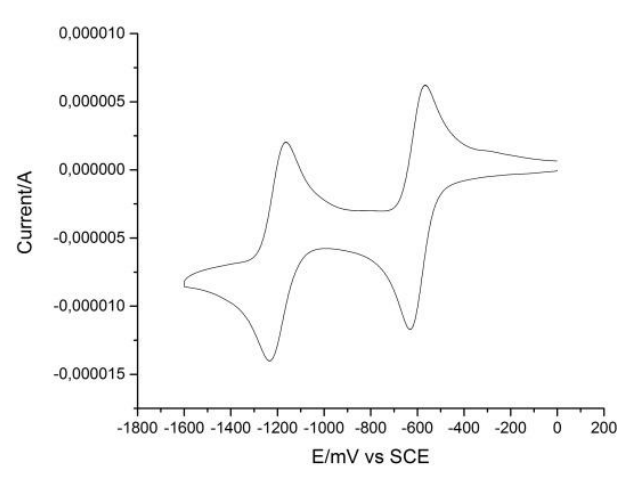

(b)

Figure 1. (a) Cyclic voltammogram of univalent compound 6;

(b) Cyclic voltammogram of divalent compound $\mathbf{5}$

Table 2 shows for homodimer 5 a shift of the $\mathrm{E}_{1 / 2}^{\mathrm{I}}$ to more positives values compared with $\mathbf{7}$, this is an expected result since ester group is more electron-withdrawing than acetyl group. But, when the $\mathrm{R}^{1}$ group was changed from $-\mathrm{Me}$ to $-\mathrm{H}$, for compounds $\mathbf{8}, 9$ and $\mathbf{1 0}$, occurs the contrary, the acetyl group in 9 displaced the $\mathrm{E}_{1 / 2}^{\mathrm{I}}$ to more positive values. On the other hand, for monomers $\mathbf{6}$ and $\mathbf{1 1}$ the tendency observed for homodimers $\mathbf{5}$ and $\mathbf{7}$ is not shown, since acetyl group in $\mathbf{1 1}$ shifts $\mathrm{E}_{1 / 2}^{\mathrm{I}}$ to more positives values instead of the ester group. Nevertheless when compound $\mathbf{6}$ and $\mathbf{1 2}$ are compared it is noticing that the compound 12 with $\mathrm{R}^{1}-\mathrm{H}$ displaced the $\mathrm{E}_{1 / 2}^{\mathrm{I}}$ to more positive values; these results do not occur with their dimeric analogs $\mathbf{5}$ and $\mathbf{8}$. Other than that, it is observed the same behavior for monomers $\mathbf{1 2}$, 13 and 14 than describe for homodimers 8,9 and 10.

\section{Conclusions}

In conclusion, the one-pot synthesis of homodimers and monoamination compounds has been optimized using MW and ultrasound-assisted techniques, obtaining better yields in shorter reaction times, making of these a suitable methodology for the synthesis of bivalent compounds in one step. Based on the results, thermodynamic and kinetic factors are relevant in the selectivity of dimer 5/ monomer 6 formation. The electrochemical study showed two redox processes for both monoamination compounds and homodimers, being this last one due to the symmetry of their structures. Also, $\mathrm{E}_{1 / 2}^{\mathrm{I}}$ values shifted to positive or negative values depending on the substituents groups, supporting the quinone nature in which their formal potential can be moderate for biological purposes.

Acknowledgments: The authors thank to Vicerrectoria de Investigación, Desarrollo e Innovación, Universidad de Santiago de Chile. DICYT Project No. 021841IR.

\section{References}

1.SAGAR, S. et al. Anticancer. Agents Med. Chem. 14, 2014, p. 170-180.

2.ABAD, M. J. \& BERMEJO, P. Stud. Nat. Prod. Chem. 30, 2005, p. 303-366.

3.EL-NAJJAR, N. et al. Phytochem. Rev. 10, 2011, p. 353-370.

4.KONDRACKY, M.-L. \& GUYOT, M. Tetrahedron Lett. 28, 1987, p. 5815-5818.

5.KONG, D., YAMORI, T., KOBAYASHI, M. \& DUAN, H. MAR. Drugs 9, 2011, p. 154-161.

6. PETTIT, G.R., KNIGHT, J.C., COLLINS, J.C., HERALD, D.L., PETTIT, R.K.; BOYD, M.R., YOUNG, V.G. J. Nat. Prod. 2000, 63, p. 793-798.

7.MILANOWSKI, D. J., GUSTAFSON, K. R., KELLEY, J. A. \& MCMAHON, J. B. J. Nat. Prod. 2004, 67, p. 70-73.

8.RYU, C.-K. et al. Med. Chem. Res.2004, 13, p. 249-258. 
9.LOWN, J. W. Mol. Cell. Biochem. 1983, 55, p. 17-40.

10.BEGLEITER, A. Biochem. Pharmacol. 1985, 34, p. 2629-2636.

11.BOLTON, J. L., TRUSH, M. A., PENNING, T. M., DRYHURST, G. \& MONKS, T. J. Chem. Res. Toxicol. 2000, 13, p. 135-160.

12.POWIS, G. Pharmacol. Ther. 1987, 35, p. 57-162.

13.O'BRIEN, P. J. Chem. Biol. Interact. 1991, 80, p. 1-41.

14.WELLINGTON, K. RSC Adv. 2015, 5, p. 20309-20338.

15.BOLTON, J. L. \& DUNLAP, T. Chem. Res. Toxicol. 2017, 30, p. 13-37.

16.PENNING, T. M. Toxicol. Res. (Camb). 2017, 6, p. 740-754.

17.MONKS, T. \& JONES, D. Curr. Drug Metab. 2005, 3, p. 425-438.

18.LUSTHOF, K. Free Radic. Biol. Med 1992, 13, p. 599-608 (1992).

19.ROBERT, P., COHEN, G. M. \& ROSS, V. D. Toxicol. Appl. Pharmacol 1992, 16, p. 2-16.

20.KIM, R. S. \& CHUNG, T. D. Bull. Korean Chem. Soc. 2014, 35, p. 3143-3155.

21.ZHOU, L. et al. Catal. Letters 2008, 125, p. 154-159.

22.MIRKHALAF, F., TAMMEVESKI, K. \& SCHIFFRIN, D. J. Phys. Chem. Chem. Phys. 2004, p. 1321-1327.

23.FIESER, L. F. \& FIESER, M. J. Am. Chem. Soc 1935, 57, p. 491-494.

24.HEFFNER, J. E., RABER, J. C., MOE, O. A. \& WIGAL, C. T., J. Chem. Educ. 1998, 75, p. 365367.

25.KAPPE, C. O. Angew. Chemie Int. Ed. 2004, 43, p. 6250-6284.

26.DESAI, N. C. \& DODIYA, A. M. ARAB. J. Chem. 2011, 9, p. S379-S387.

27.NAIN, S., SINGH, R. \& RAVICHANDRAN, S., Adv. J. Chem. 2019, A 2, p. 94-104.

28.LIDSTRÖM, P., TIERNEY, J., WATHEY, B. \& WESTMAN, J., Tetrahedron, 57, p. 9225-9283.

29.BAIG, R. B. N. \& VARMA, R. S. Chem. Soc. Rev. 2012, 41, p. 1559-1584.

30.CRAVOTTO, G. \& CINTAS, P. Chem. Soc. Rev. 2006, 35, p. 180-196.

31.KIMURA, T. Sonochemistry and the Acoustic Bubble 2015, p. 171-186.

32.CRAVOTTO, G. \& CINTAS, P. Chem. - A Eur. J. 2007, 13, p. 1902-1909.

33.LI, J. T., CUI, Y., CHEN, G. F., CHENG, Z. L. \& LI, T. S. Synth. Commun. 2003, 33, p. 353-359.

34.WANG, S. Y., JI, S. J. \& LOH, T. P. Synlett 2003, p. 2377-2379.

35.BANDYOPADHYAY, D., MUKHERJEE, S., TURRUBIARTES, L. C. \& BANIK, B. K. Ultrason.

Sonochem. 2012, 19, p. 969-973.

36.GANGRADE, D., SD, L. \& AL, M. Int J Res Pharm Sci 2015, 5, p. 37-42.

37.BERRINO, E. \& SUPURAN, C. T. Expert Opin. Drug Discov. 2018, 00, p. 1-13.

38.DE LA HOZ, A., DÍAZ-ORTIZ, A. \& PRIETO, P. Alternative Energy Sources for Green Chemistry, 47, Royal Society of Chemistry, Stefanidis, G., Stankiewickz, A.,United Kingdom, 2016, p. 1-33.

39.AMORE, K. M., LEADBEATER, N. E., MILLER, T. A. \& SCHMINK, J. R. Tetrahedron Lett. 2006, 47, p. 8583-8586.

40.SURYA PRAKASH RAO, H. \& JOTHILINGAM, S. J. Chem. Sci. 2005, 117, p. 323-328.

41.IBACACHE, J. A., FAUNDES, J., MONTOYA, M., MEJIAS, S. \& VALDERRAMA, J. A. Molecules 2018, 23, p. 439

42.VALDERRAMA, J.A., IBACACHE, J.A., ARANCIBIA, V.; RODRIGUEZ, J., THEODULOZ, T. Bioorg Med Chem. 2009, 17, p. 2894-2901.

43.DELGADO, V., IBACACHE, J.A., ARANCIBIA, V., THEODULOZ, C., VALDERRAMA, J.A. Molecules 2013, 18, p. 721-734.

44.IBACACHE, J. A., VALDERRAMA, J.A., FAUNDES, J., DANIMANN, A., RECIO, FRANCISCO J., ZUNIGA, C. Molecules 2019, 24, p. 1-13.

Manuscript received: 21.01 .2020 